\title{
Pola Pengelolaan BUMDes Berbasis Syariah Sebagai Alternatif Pemberdayaan Usaha Mikro Masyarakat Perdesaan
}

\author{
Suhirman \\ Program Studi Perbankan Syariah, Fakultas Ekonomi dan Bisnis Islam, \\ UIN Walisongo Semarang, Indonesia \\ Email: suhirman@walisongo.ac.id
}

\begin{abstract}
:
Village-Owned Enterprises (BUMDes) are institutionally growing very fast. However, the roles of BUMDes as an agency of rural economy have not been optimal to provide solutions to the socio-economic problems of rural communities. This is due to the concept of BUMDes management that has not developed patterns to facilitate economic growth and to empower the existing micro-enterprises. Based on the problems, this article offers a sharia-based management concept of BUMDes as a solution to address socio-economic problems through empowering micro-business in rural communities. This article uses qualitative method with secondary data analyzed descriptively. This article concludes BUMDes management prioritizing benefits, partnerships and risk mitigations that accord with the rural context can be non-banked financial inclusion (IKNB) and can spur growth and capability of microenterprises in rural communities sustainably. By increasing the capability of micro enterprises, it can be a solution to the socio-economic problems of rural communities.
\end{abstract}

Keywords: Village-Owned Enterprises, sharia, empowerment, micro-enterprises, growth.

\begin{abstract}
Abstrak:
Badan Usaha Milik Desa (BUMDes) secara kelembagaan mengalami pertumbuhan yang sangat pesat. Akan tetapi, hingga saat ini peran BUMDes sebagai badan ekonomi di perdesaan belum optimal dan mampu menjadi solusi terhadap permasalahan sosial ekonomi yang dihadapi masyarakat di beberapa desa. Hal ini dikarenakan konsep pengelolaan BUMDes belum mengarah kepada pola-pola yang bertujuan mendorong pertumbuhan dan melakukan usaha-usaha pemberdayaan usaha mikro masyarakat yang sudah ada. Berdasarkan permasalahan tersebut maka artikel ini menawarkan sebuah konsep pengelolaan BUMDes yang berbasis syariah sebagai solusi mengatasi permasalahan sosial ekonomi melalui pemberdayaan usaha mikro masyarakat perdesaan. Metode penulisan yang dignakan adalah kualitatif dengan data skunder yang dianalisis secara kualitatif-deskiptif. Artikel ini menyimpulkan bahwa pola pengelolaan BUMDes yang berbasis pada pengutamaan kemaslahatan, kemitraan, dan mitigasi risiko yang sesuai dengan konteks pedesaan dapat menjadi inklusi keuangan non bank (IKNB) yang mampu memacu pertumbuhan dan meningkatkan kapabilitas usaha mikro masyarakat perdesaan secara sustainable. Dengan meningkatnya kapabilitas usaha mikro dapat menjadi solusi bagi permasalahan sosial ekonomi masyarakat perdesaan.
\end{abstract}

Kata Kunci: BUMDes, syariah, pemberdayaan, usaha mikro, pertumbuhan. 


\section{PENDAHULUAN}

Permasalahan kemiskinan dan ketimpangan sosial ekonomi selalu menjadi perbincangan hangat di setiap negara. Kemiskinan identik dengan perdesaan dan ketimpangan sosial ekonomi terang-benderang terlihat di perkotaan. Perbincangan tentang keduanya terus mengemuka dan tak lekang oleh waktu. Perdesaan identik dengan kemiskinan karena sektor ekonomi yang diandalkan oleh penduduk desa adalah sektor pertanian. Hasil pertanian tak selalu menguntungkan bagi penduduk desa karena dua faktor: hama (penyakit tanaman) dan harga pasar hasil produksi pertanian yang sering tak bersahabat dengan petani. Oleh karena itu, kemiskinan di perdesaan seolah menjadi identitas laten yang sulit dilenyapkan, termasuk di Indonesia. Hal ini bisa dilihat masih tingginya jumlah penduduk miskin di perdesaan sebagaimana yang dapat dilihat dari data yang dirilis BPS Bulan Juli 2020 yang lalu. Data BPS menunjukkan jumlah penduduk miskin di perdesaan Indonesia sebanyak 15,26 Juta Orang dari total 26,42 (9,78\%) Juta Orang. ${ }^{1}$ Data ini meperlihatkan bahwa perdesaan masih mendominasi sebagai penyumbang angka kemiskinan di Indonesia.

Dominasi perdesaan sebagai penyumbang angka kemiskinan tidak lepas dari dualisme sektor perekonomian di Indonesia: sektor tradisonal yang meliputi pertanian dan sektor modern yang meliputi industri di perkotaan. Dualisme perekonomian ini berperan secara laten menciptakan ketimpangan di antara penduduk desa dengan kota. Oleh karena itu, menurut Boeke, sebagaimana dikutip Hardijono dkk, sektor tradisional harus diberikan insentif ekonomi dan peningkatan teknologi produksi. ${ }^{2}$ Di Indonesia, insentif ekonomi yang diberikan pemerintah saat ini yaitu berupa dana desa (DD) dan alokasi dana desa (ADD) yang cukup besar jumlahnya. DD dan ADD diproyeksikan sebagai stimulus guna meningkatkan produktivitas desa dalam rangka mengembangkan kemandirian dan kesejahteraan masyarakat desa. ${ }^{3}$ Melalui insentif ekonomi ini, diharapkan desa berperan aktif turut serta membangun perekonomian nasional dari bawah/pinggiran.

DD dan ADD bagi desa merupakan lokomotif utama untuk menggerakkan perekonomian di perdesaan. Oleh banyak desa, adanya DD dan ADD ini dijadikan sebagai momentum untuk mendirikan suatu badan ekonomi independen yang disebut BUMDes (Badan Usaha Milik Desa). Sebagian dari DD dan/atau ADD ini dialokasikan sebagai penyertaan modal desa kepada BUMDes. Kelembagaan BUMDes dari tahun ke tahun mengalami pertumbuhan yang signifikan, sebagaimana terlihat pada grafik berikut:

1 https://www.bps.go.id/website/images/Kemiskinan-Rilis-Juli-2020-ind.jpg, diakses, 19 Agustus 2020.

${ }^{2}$ Rachmat Hardijono and others, 'Economic Independence Of The Village Through Institutional Village Enterprises (BUMDes)', IOSR Journal of Economics and Finance, 3.2 (2014), 21-30 <https://doi.org/10.9790/5933-03232130>.

3 Permendesa, 'Peraturan Menteri Desa, Pembangunan Daerah Tertinggal, Dan Transmigrasi No. 5 Tahun 2015 Tentang Penetapan Prioritas Penggunaan Dana Desa', 1-6. 
Grafik 1

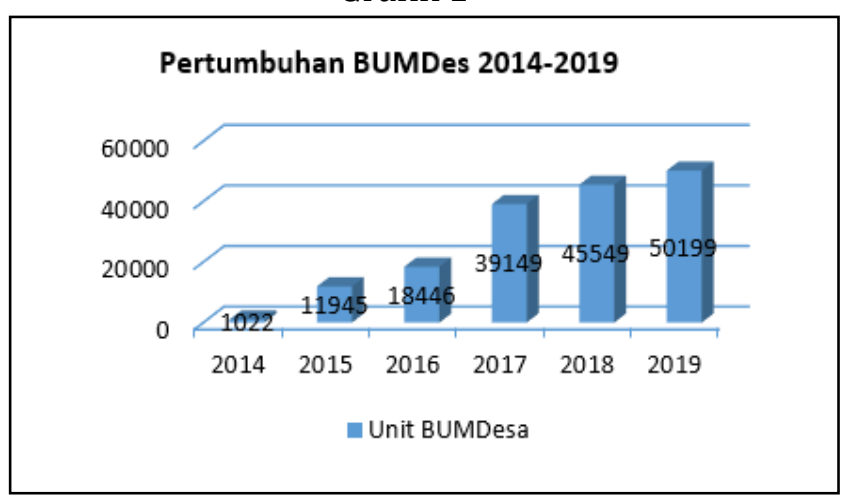

Sumber: Kemendes PDTT; diolah

Grafik di atas menunjukkan pertumbuhan pesat terjadi pada tahun 2015 yaitu 1068,79 \%. Data terakhir, Tahun 2019, jumlah BUMDesa mencapai 50.199 unit yang tersebar diseluruh Indonesia. Ini artinya jumlah BUMDes mencapai $67 \%$ dari 74.954 jumlah desa yang ada. Lonjakan ini terjadi, terutama Tahun 2015, karena pada waktu itu desa memperoleh anggaran berupa DD dan ADD yang cukup besar dibandingkan tahun-tahun sebelumnya. Anggaran yang besar ini kemudian dipandang sebagai peluang untuk membangun ekonomi desa secara mandiri melalui BUMDes. DD dan ADD yang besar dan didukung BUMDes yang bergerak dalam bidang usaha-bisnis diasumsikan sebagai momentum yang tepat bagi desa untuk menuju kemandirian ekonomi. ${ }^{4}$ Asumsi ini sesungguhnya tiak berlebihan karena melihat potensi capital yang dimiliki desa saat ini, baik finansial atau pun sosial.

Menurut Yusuf dkk, BUMDes yang dikelola secara maksimal dan profesional dapat menjadi sumber utama pendapatan asli desa (PADes). ${ }^{5}$ Potensi ini sangat memungkinkan bagi BUMDes, karena dalam menjalankan usahanya, BUMDes dapat mengelola semua potensi yang ada di desa. Sebagaimana diketahui, setiap desa memiliki potensi masing-masing sehingga memungkinkan setiap desa dapat memiliki produk unggulan masing-masing, one village one product. Di samping itu, dalam pengelolaannya, BUMDes dapat melibatkan semua elemen masyarakat yang didasarkan nilai-nilai sosial yang hidup di tengah-tengah masyarakat. ${ }^{6}$ Keterlibatan masyarakat dalam BUMDes dapat menjadi mesin ekonomi bagi masyarakat sehingga semua masyarakat memiliki sumber penghasilan yang sustainable. Dengan demikian, posisi BUMDes dapat menjadi lumbung ekonomi bagi pemerintah desa dan masyarakat umum.

Potensi BUMDes sebagai lumbung ekonomi yang mampu menggerakkan perekonomian nasional dari pinggiran sangat besar. Akan tetapi, harapan tidak selalu seirama dengan fakta di lapangan. Hasil penelitian Razak dan Sofyan menunjukkan, BUMDes belum mampu

\footnotetext{
4 Muryanti Muryanti, 'Towards Social Entrepreneurship in the Village through Village-Owned Enterprises', Society, 8.1 (2020), 163-74 <https://doi.org/10.33019/society.v8i1.161>.

${ }^{5}$ Edy Yusuf and others, 'Strategy for the Development of Coastal Village-Owned Enterprises ( Bumdes ) As a Form of Independent', International Journal of Mechanical Engineering and Technology, 10.06 (2019), 160-69.

6 Muhammad Rais Rahmat Razak and B. Sofyan, 'Role of Village-Owned Enterprises in Farming Community Empowerment', International Journal of Advanced Science and Technology, 29.6 Special Issue (2020), 684-91.
} 
menjadi lokomotif untuk pemberdayaan masyarakat.7 Penelitian Ibrahim juga menyajikan data yang senada, ada beberapa temuan ketidakberpihakan pengelolaan BUMDes terhadap pemberdayaan ekonomi masyarakat. BUMDes belum dikelola secara profesional. Potensi ekonomi yang bersumber dari sumber daya alam yang ada di desa-desa belum terorganisir secara baik. Demikian pula dari aspek manajemen sehingga beberapa program BUMDes tidak tepat sasaran. Beberapa program kerja yang dilakukan BUMDes tidak berorientasi pada peningkatan ekonomi masyarakat. ${ }^{8}$ Fakta serupa diungkapkan Afwa bahwa BUMDes di Banyumas belum optimal karena payung hukum implementasinya tidak mendukung. Aspek manajerialnya masih tergolong rendah akibat sumber daya yang masih buruk, fasilitas dan infrastruktur yang tidak memadai. ${ }^{9}$ Poin utamanya, menurut Winarsi dkk, adalah BUMDes dapat mewujudkan tujuan utamanya apabila BUMDes dikelola secara profesional, amanah, dan berkeadilan; tanpa demikian, sulit bagi BUMDes untuk merealisasikan tujuan utamanya. ${ }^{10}$

Permasalahan di atas merupakan permasalahan klise yang selalu terjadi hampir di setiap instansi dan lembaga. Untuk mengatasinya, dibutuhkan satu solusi yang secara sistemik-operasional yang dibangun dari kesadaran religiusitas dan budaya (culture) yang hidup di tengah-tengah masyarakat di mana BUMDes itu hidup. Kesadaran religiusitas untuk membangun sebuah sisem pengelolaan ekonomi sangat penting. Dalam konteks Islam, menurut Nuruzzaman, seorang muslim yang memiliki islamic worldview akan memiliki rasionalitas berbeda yang akhirnya akan bermuara pada apa yang disebut huquq. Huquq yang dimiliki seorang muslim akan menggiringnya menjadi manusia yang tidak hanya mementingkan diri sendiri (self interest) melainkan selalu mengutamakan kepentingan sosial bahkan lingkungan alam sekitarnya. ${ }^{11}$

Demikian halnya pendapat Pradja, menurutnya penghayatan terhadap nilai-nilai yang terkandug dalam agama dan budaya dapat mengarahkan seseorang menjadi manusia yang profesional dan bertanggungjawab. ${ }^{12}$ Seorang yang memiliki sifat seperti ini dalam bermuamalah akan menjadikan penalaran maqasid al-syariah sebagai basis epistemologi tindakannya. Maqasid al-syariah dalam muamalah (ekonomi) memiliki tujuan utama, yaitu menciptakan kesejahteraan umat secara universal (mashlahah al-'ammah).13 Islam sebagai agama yang mengemban misi rahamah li al-'alamin sangat konsens terhadap hal ini. Di mana dukungan Islam terhadap profesinalitas dan tanggungjawab dalam sebuah pekerjaan merupakan keniscayaan yang tidak bisa ditawar.

\footnotetext{
${ }^{7}$ Razak and Sofyan.

${ }^{8}$ Ibrahim, 'Productivity the Village Owned Enterprises to Improve the Economic Community of Gold Mining Areas in Sumbawa Island, Indonesia', International Journal of Scientific and Technology Research, 9.2 (2020), 235-38.

${ }^{9}$ Ulil Afwa, 'Local Economic Development Manifesto: Policy Analysis on the Implementation of VillageOwned State Enterprises', SHS Web of Conferences, 54 (2018), $04002<\mathrm{https} / / / \mathrm{doi} .0 \mathrm{rg} / 10.1051$ /shsconf/20185404002>.

${ }^{10}$ Sri Winarsi and others, "The Law Principles for Village-Owned Enterprises (BUMDes) Management in Indonesia to Improve the Village's Economy', International Journal of Sociological Jurisprudence, 1.2 (2018), 130-36.

11 Mohamad Soleh Nurzaman, Pengantar Ekonomi Islam: Sebuah Pendekatan Metodologi (Jakarta: Salemba Diniyah, 2019).

${ }^{12}$ Juhaya S. Pradja, Ekonomi Syariah (Bandung: Pustaka Setia, 2015).

${ }^{13}$ Moh. Mufid, Ushul Fiqh Ekonomi Dan Keuangan Kontemporer, 2nd edn (Jakarta: Prenanda Media Group, 2018).

4

Iqtishadia: Jurnal Ekonomi dan Perbankan Syariah

Vol.8 No.1 Juni 2021
} 
Selama ini, religiusitas dan budaya lokal (local wisdom) sebagai asas dalam menjalankan aktifitas ekonomi cenderung dinihilkan. Berabad-abad lamanya ekonomi dunia didominasi oleh prilaku kapitalisme. Kapitalisme telah menjadi worldview para pelaku ekonomi sejak lama. Dalam sistem ekonomi kapitalis, tidak ada hukum yang mengikat kecuali hal-hal yang berpotensi merugikan bisnis, dan di sini perbedaan mendasarnya dengan ekonomi Islam. Dalam ekonomi Islam, menurut Muslimin, hukum merupakan hal yang inhern, tidak bisa dipisahkan dari aktifitas ekonomi. ${ }^{14}$ Sistem ekonomi yang memegang prinsip seperti ini dalam konteks sekarang merupakan alternatif yang harus dipertimbangkan.

Ketidakadilan dan ketimpangan ekonomi masih menjadi momok yang seolah tak bisa dikikis secara tuntas. Ketidakadilan dan ketimpangan ekonomi ini sangat nyata ketika melihat kehidupan masyarakat di perdesaan. Masyarakat perdesaan masih jauh dari kategori sejahtera karena kapabilitas mereka rata-rata masih rendah. Program-program selama ini yang dibiayai dari DD dan ADD belum menyentuh secara signifikan terhadap peningkatan kapabilitas masyarakat melalui program-program seperti pemberdayaan. Hasil penelitian Bachtiar dkk mengungkapkan, bahwa belanja desa masih didominasi pada sektor infrastruktur. Belanja desa untuk kegiatan pemberdayaan masih sangat minim, bahkan ditemukan beberapa desa sama sekali tidak melakukan kegiatan pemberdayaan. ${ }^{15}$

Fakta ini sangat ironis ketika berbicara tentang kesejahteraan dalam pembangunan ekonomi. Menurut Sen, dalam pembangunan ekonomi, peningkatan kapabilitas masyarakat merupakan hal mutlak dilakukan untuk mencapai kesejahteraan. ${ }^{16}$ Bahkan menurut Soto, kapabilitas rendah telah menyebabkan banyak orang tidak bisa menyibak misteri sukses melalui kapitalisme. Kata Soto, mereka tidak memiliki kapabilitas memadai dalam memanfaatkan capital (modal) yang mereka miliki menjadi mesin uang. Fakta ini tidak hanya terjadi di negara-negara terbelakang, melainkan banyak pula terjadi di negara-negara berkembang seperti Indonesia. ${ }^{17}$ Dalam konteks seperti inilah kemudian tulisan ini menawarkan sebuah konsep pengelolaan BUMDes berbasis syariah.

Untuk mencapai tujuan itu, BUMDes harus memiliki sistem operasional yang tangguh yang sesuai dengan konteks perdesaan. Berawal dari hal ini, tulisan ini bertujuan untuk mengkonstruksi konsep operasional BUMDes berbasis syariah untuk meningkatkan kapabilitas masyarakat perdesaan. Apabila konsep ini nantinya diimplementasikan secara baik, maka BUMDes berbasis syariah ini dapat menjadi alternatif inklusi keuangan non bank (IKNB) syariah yang berperan aktif dalam rangka mengakselerasi penguatan sosial ekonomi masyarakat perdesaan.

\section{METODE PENELITIAN}

Penelitian ini merupakan penelitian kualitatif, yaitu penelitian yang memandang objek sebagai sesuatu yang utuh, dinamis, hasil konstruksi pemikiran, dan interpretasi terhadap gejala yang diamati, serta utuh (holistic) karena setiap aspek dari objek mempuanyai satu

\footnotetext{
${ }^{14} \mathrm{~J}$ M Muslimin, 'Society, Law and Economy: Contextualizing Ibn Khaldun's Thought', Al-Iqtishad: Jurnal Ilmu Ekonomi Syariah (Journal of Islamic Economics), 11.July (2019), 167-80.

${ }^{15}$ Palmira Bachtiar and others, Laporan Studi Kasus Undang-Undang Desa: Menelusuri Manfaat Belanja Desa (Jakarta: Smeru Research Institite, 2019) <https://smeru.or.id>.

${ }^{16}$ Se'verine Deneulin and J. Allister McGregor, "The Capability Approach and The Politics of a Social Conception of Wellbeing', European Journal of Social Theory, 13.4 (2010), 501-19.

${ }^{17}$ Hernando de Soto, The Mystery of Capital (t.t.p: Qalam, 2006). 
kesatuan yang tidak dapat dipisahkan. ${ }^{18}$ Data yang digunakan adalah data sekunder yang diperoleh melalui penelitian kepustakaan (library research) berupa jurnal, buku, dan sumber terkait lainnya.

Analisis data dilakukan secara kualitatif, yaitu memandang realitas sebagai konstruksi atau interpretasi dari pemahaman terhadap data yang tampak. ${ }^{19}$ Metode analisis kualitatif ini dilakukan dengan proses melakukan pembacaan, menelaah, dan mengkaji data-data berupa dokumen atau laporan, jurnal, buku, dan sumber lainnya yang berkaitan dengan fokus masalah dalam penelitian. Hasil analisis literatur, kemudian dinarasikan sebagai sebuah data yang dikonstruksi dari kesimpulan hasil pembacaan terhadap literatur yang terhimpun.

\section{HASIL DAN PEMBAHASAN}

Hasil dan pembahasan meliputi lima (5) bahasan pokok, pertama BUMDes berbasis syariah dalam perspektif regulasi. Bagian ini membahas tentang bagaimana kemungkinan BUMDes dikelola secara syariah menurut regulasi yang ada. Pokok bahasan kedua, BUMDes business network: mengarusutamakan maslahat. Bagian ini membahas tentang bagaimana pola jaringan bisnis BUMDes yang mengutamakan kemaslahatan sehingga berdampak pada penguatan sosial ekonomi masyarakat. Pokok bahasan ketiga, implementasi akad pemiayaan berbasis kerjasama. Bagian ini membahas tentang bagaimana skema pembiayaan agar sesuai dengan teori yang mudah dipahami oleh masyarakat awam dan mampu memberi sumbangan terhadap percepatan-percepatan pembangunan sosial ekonomi masyarakat desa. Pokok bahasan keempat, mitigasi risiko pendekatan kontekstual: sekenario menghindari non performing loan. Bagian ini membahas tentang bagaimana pola mitigasi risiko yang dapat digunakan untuk meminimalisir terjadi risiko pembiayaan yang sesuai dengan konteks perdesaan. Dan pokok bahasan kelima yang merupakan bahasan terakhir membahas tentang Implikasi BUMDes Berbasis Syariah terhadap Pemberdayaan Sosial Ekonomi Masyarakat Perdesaan. Bagian ini menerangkan bagaimana korelasi pola pengelolaan BUMDes dengan terciptanya pengutan-pengutan sosial ekonomi masyarakat perdesaan.

\section{BUMDes Berbasis Syariah: Perspektif Regulasi}

Pemerintah berkomitmen merubah arah pembangunan di Indonesia melalui perubahan jargon dari "membangun desa" menjadi "desa membangun." Desa membangun artinya pemerinah hendak menempatkan desa sebagai subjek pembangunan. Selama ini, desa selalu diposisikan sebagai objek pembangunan. Sebagai objek, tidak selalu menguntungkan bagi desa. Sering kali pola pembangunan yang dilakukan tidak sesuai dengan apa yang dibutuhkan oleh desa itu sendiri. Potensi dan kebutuhkan masing-masing desa bisa berbedabeda. Ketika potensi dan kebutuhkan ini tidak terakomodir dengan baik maka tujuan pembangunan menjadi tidak terarah.

Pemerintah, sebelumnya sudah melakukan berbagai upaya dalam rangka meningkatkan perekonomian masyarakat desa. Program Nasional Pemberdayaan Masyarakat (PNPM) adalah salah satu program yang dilakukan oleh pemerintah. PNPM dalam perjalanannya, menurut Kuncoro, belum bisa merealisasikan tujuannya dengan maksimal. PNPM belum bisa menyentuh masyarakat miskin secara keseluruhan. Demikian pula

\footnotetext{
${ }^{18}$ Sugiyono, Metode Penelitian Kombinasi (Mixed Methods), 8th edn (Bandung: Alfabeta, 2016).

${ }^{19}$ Sugiyono.

6

Iqtishadia: Jurnal Ekonomi dan Perbankan Syariah

Vol.8 No.1 Juni 2021
} 
kebutuhan masyarakat pinggiran, belum mampu dijangaku secara maksimal dan merata. ${ }^{20}$ Program-program lain seperti Program Pengentasan Kemiskinan Perkotaan (P2KP) dan Program Percepatan Pembangunan Desa Tertinggal (P3DT) pun belum bisa menjadi solusi yang mampu mengatasi masalah secara efektif dan tepat. ${ }^{21}$ Belajar dari program-program yang telah dilakukan ini, pemerintah memandang perlu dilakukan perubahan paradigma pembangunan dengan menjadikan desa sebagai subjek pembangunan. Paradigma ini mengarahkan desa sebagai pelaku independen untuk menentukan arah kehidupannya secara mandiri. Desa bisa mendesain berbagai program yang sesuai dengan potensi dan kebutuhannya.

Posisi desa sebagai subjek pembangunan didukung oleh pemerintah dengan menerbitkan Undang-Undang No. 6 Tahun 2014 tentang Desa. Undang-Undang ini kemudian diikuti dengan Peraturan Meneteri Desa, Pembangunan Daerah Teringgal, dan Transmigrasi No. 4 Tahun 2015 tentang Pendirian, Pengurusan dan Pengelolaan, dan Pembubaran Badan Usaha Milik Desa. Permendesa ini kemudian yang menjadi payung hukum pendirian BUMDes yang konstitusional. Di dalam permendesa ini dijelaskan pula bentuk usaha yang boleh dilakukan oleh BUMDes.

BUMDes boleh melakukan usaha apa saja selama usaha itu menguntungkan. Demikian pula dalam hal pembagian hasil usaha antara pengelola dengan pemilik modal (pemerintah desa). Pembagian hasil usaha tidak dijelaskan secara eksplisit dalam permendesa. Pembagiannya diatur dalam Anggaran Dasa/Anggaran Rumah Tangga (AD/ART) BUMDes. Ini artinya bahwa dalam hal pengelolaan BUMDes diamanatkan pada kebijakan pihak-pihak terkait yang diputuskan dalam Musyawarah Desa (MUSDes) yang dituangkan dalam AD/ART BUMDes. Oleh karena itu, dalam perspektif regulasi, tidak menjadi masalah apabila BUMDes dikelola secara syariah karena tidak ada regulasi yang secara tegas menyatakan pengelolaannya dengan sistem tertentu.

\section{BUMDes Business Network: Mengarusutamakan Mashlahah}

Ulama memberi satu kaidah dasar dalam aktivitas ekonomi:

$$
\text { الاصل في المعاملات الاباحة الا ان يدل دليل على تحريمها }
$$

"Pada dasarnya, semua bentuk muamalah boleh dilakukan kecuali ada dalil yang mengharamkannya."

Menurut kaidah ini semua bentuk bisnis boleh dilakukan selama tidak ada dalil yang melarang. Selain bertumpu pada dalil, aktivitas ekonomi harus pula bersandar pada nilai-nilai kemaslahatan. ${ }^{22}$ Mashlahah merupakan barometer utama atas seluruh aspek kehidupan dalam Islam, maka dari itu semua aktivitas seorang muslim harus disandarkan pada mashlahah.

Mashlahah secara mutlak merupakan upaya mengejawantahkan manfaat dan pada saat yang bersamaan menghindari mudarat. ${ }^{23}$ Segala bentuk kemanfaatan yang bisa diwujudkan dan dirasakan merupakan mashlahah. Kendati demikian, para ushulyin berbeda pandangan dalam merumuskan mashlahah walaupun secara esensial memiliki kesamaan-

${ }^{20}$ Mudrajad Kuncoro, Mudah Memahami Dan Menganalisis Indikator Ekonomi (Yogyakarta: UPP STIM YKPN, 2013).

${ }^{21}$ Kemal A. Stamboel, Panggilan Keberpihakan: Stategi Mengakhiri Kemiskinan Di Indonesia (Jakarta: Gramedia Pustaka Utama, 2012).

22 Moch Bukhori Muslim, Saepullah Saepullah, and Any Widayatsari, 'Political Economy From the Perspective of Ibn Khaldun', Al-Iqtishad: Jurnal Ilmu Ekonomi Syariah, 11.1 (2019), 59-74 $<$ https://doi.org/10.15408/aiq.v11i1.13341>.

${ }^{23}$ Abdul Wahhab Khallaf, 'Ilmu Ushul Al-Fiqh (Kairo: Al-Haramain, 2004). 
kesamaan yang mendasar. Al-Ghazali membatasi mashlahah pada kemaslahatan yang dikehendaki oleh syari', Allah dan Rasul-Nya. Kemaslahatan yang dikehndaki syari' yang dimaksud oleh al-Ghazali adalah kemaslahatan yang bermuara pada terpeliharanya lima dimensi; agama, jiwa, akal, keturunan, dan harta. Semua kemaslahatan yang mengarah pada lima dimensi ini merupakan mashlahah dan apa saja yang menghalanginya merupakan mafsadah. ${ }^{24}$ Menurut Nahe'i dan Juandi, al-Ghazali hanya membatasi mashlahah dengan yang dikehndaki oleh Syari'. Sementara mashlahah yang didasarkan pada pertimbangan akal manusia bukanlah mashlahah. ${ }^{25}$ Maka menurut pandangan ini, mashlahah harus dirokemdasikan oleh dalil-dalil yang bersumber dari Alqur'an dan Hadits sebagai manifestasi kehendak Syari'. Tanpa demikian maka kemaslahatan tersebut bukan kemaslahatan yang dikehendaki oleh al-Ghazali.

Pandangan al-Ghazali itu berbeda dengan al-Syathibi. Menurut al-Syathibi, mashlahah pada dasarnya tidak bisa diidentifikasi apakah sesuai dengan kehendak Syari' atau tidak. Menurutnya, mashlahah pasti sesuai dengan kehendak Syari'. ${ }^{26}$ Mashlahah sejatinya adalah kebaikan-kebaikan yang bertumpu pada terpeliharanya lima dimensi yang diungkapkan alGhazali di atas. Lain halnya dengan al-Thufi, ia memahami mashlahah dalam dua kategori, mashlahah dalam pandangan 'urf dan mashlahah dalam pandangan syar'i. Mashlahah 'urf merupakan mashlahah yang lahir dari tradisi masyarakat yang berdampak positif pada semua aspek kehidupan masyarakat. Sedangkan mashlahah dalam pandangan Syari' merupakan sarana yang mengantarkan pada tercapainya tujuan Syari' yang bisa berupa ibadah atau dari tradisi masyarakat. ${ }^{27}$

Al-Thufi lebih lanjut memandang bahwa mashlahah adalah esensial syariah yang paling utama. Dalam bahasa yang lebih ekstrim, al-Thufi berpendapat apabila terjadi pertentangan antara mashlahah dengan nash (Alqur'an maupun hadits) dan atau ijma' maka mashlahah harus didahulukan. Argumentasinya, nash dan ijma' adalah sarana untuk mencapai tujuan hukum (al-wasa'il) sedangkan mashlahah merupakan tujuan hukum (almaqashid). Berdasarkan argumentasi ini maka al-maqashid harus didahulukan dari pada alwasa'il. $^{28}$

Perdebatan ulama tentang posisi mashlahah, sebagaimana di atas, mencerminkan bahwa mashlahah merupakan hal yang paling mendasar dalam Islam. Semua ulama ketika membahas tentang hukum pasti mengaitkelindankan dengan mashlahah. Maka dari itu, umat Islam harus memposisikan mashlahah sebagai tujuan utama dalam menjalankan aktivitas kesehariannya, termasuk pada sektor lembaga keuangan seperti perbankan. ${ }^{29}$ Atas dasar ini, pengarusutamaan mashlahah dalam aktivitas ekonomi menjadi hal yang fundamental. Karena sektor ekonomi, dalam paradigma Islam, masuk pada ranah fikih sehingga cara kerja ekonomi tidak bisa lepas dari esensi utama fikih yang dirumuskan para ulama. ${ }^{30}$ Esensial

\footnotetext{
${ }^{24}$ Saikh Muhammad Al-Ghazali, Al-Mustashfa (Beirut: Dar al-Fikr).

${ }^{25}$ Imam Nahe'i and Wawan Juandi, Revitalisasi Ushul Fiqh Dalam Proses Istinbath Hukum Islam (Sirubondo: Ibrahimy Press, 2010).

${ }^{26}$ Al-Syathibi, Al-Muafaqat Fi Ushul Al-Syari'ah (Beirut: Dar al-Ma'arif).

27 Nahe'i and Juandi.

${ }^{28}$ Abdul Wahhab Khallaf, Mashadir Al-Tasyri' Al-Islami Fima La Nashsha Fih (Kuwait: Dar al-Qalam, 1972).

${ }^{29}$ Muhammad Nadratuzzaman Hosen and others, "The Effect of Financial Ratios, Maqasid Sharia Index, and Index of Islamic Social Reporting to Profitability of Islamic Bank in Indonesia', Al-Iqtishad: Jurnal Ilmu Ekonomi Syariah, 11.2 (2019), 201-22 <https://doi.org/10.15408/aiq.v11i2.11588>.

${ }^{30}$ Muslimin.

8

Iqtishadia: Jurnal Ekonomi dan Perbankan Syariah

Vol.8 No.1 Juni 2021
} 

utama fikih, menurut para ulama, adalah mewujudkan kemaslahatan bagi umat manusia. Oleh karena itu, dalam membangun jejaring bisnis (busniess network) harus mengutamakan kemaslahatan dalam memformulasikannya.

BUMDes sebagai badan ekonomi desa harus dikelola dengan mempertimbangkan kemaslahatan sosial ekonomi masyarakat desa. Bisnis yang dijalankan BUMDes harus mencerminkan misi-misi kemaslahatan bersama sehingga mampu menjadi penggerak ekonomi dari akar rumput (grass roots) dan pinggiran. Permendesa No. 4 Tahun 2015 menyebutkan berbagai macam jenis usaha yang bisa dijalankan oleh BUMDes. BUMDes bisa menjalankan bisnis sosial (social business), bisnis penyewaan (renting), usaha perantara (brokering), usaha produksi atau berdagang (trading), bisnis keuangan (financial business), dan usaha bersama (holding). Setiap unit usaha ini memiliki spesifikasi masing-masing, sebagaimana yang telah dirinci dalam Permendesa.

Jenis usaha yang bisa dikelola BUMDes sebagaimana dijelaskan di atas tentunya tidak semua harus dijalankan. Dalam konteks pengelolaan BUMDes berbasis syariah, maka harus mempertimbangkan nilai-nilai kemaslahatan. Karakteristik jejaring bisnis BUMDes harus dibangun berdasarkan pengarusutamaan maslahat ekonomi masyarakat desa. Karakteristik seperti ini bisa menjadi pembeda dengan tata kelola BUMDes yang dikelola secara konvensional. BUMDes syariah harus mempertimbangkan jenis-jenis usaha yang tengah dijalankan masyarakat sekitar. BUMDes harus menghindari jenis-jenis usaha yang tengah dijalankan oleh masyarakat. Hal ini untuk menghindari persaingan antara BUMDes dengan masyarakat. jangan sampai keberadaa BUMDes menjadi ancaman terhadap usaha-usaha masyarakat. Untuk lebih tepatnya, BUMDes harus menghindari menjual produk-produk yang menjadi pokok jualan usaha masyarakat kecuali produk mentah untuk kebutuhan produksi usaha masyarakat. Basis usaha yang dibangun BUMDes adalah usaha kemitraan untuk saling menguatkan dan menguntungkan.

BUMDes business network yang dimaksudkan di atas dapat disimplifikasi melalui skema berikut:

Gambar 1

Skema BUMDes Buniness Network

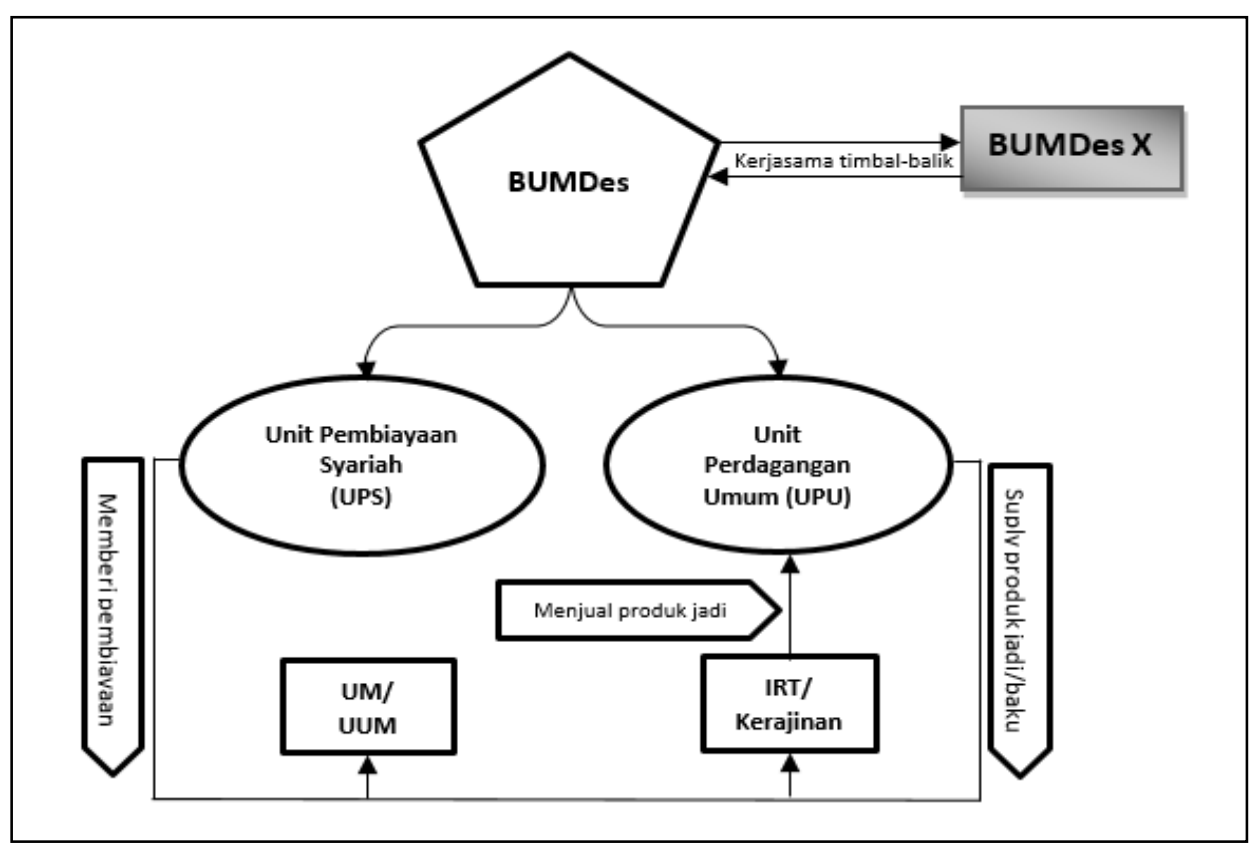

Iqtishadia: Jurnal Ekonomi dan Perbankan Syariah

Vol. 8 No. 1 Juni 2021 
Skema ini menunjukkan bahwa pola usaha BUMDes berbasis kemitraan yang memiliki dua fungsi secara bersamaan: BUMDes sebagai supplyer dan BUMDes sebagai demander. Sebagai supplyer, BUMDes menyediakan produk-produk yang dibutuhkan oleh usaha masyarakat. Sebagaimana diketahui, lazimnya usaha di perdesaan adalah mayoritas usaha mikro (UM) dan usaha ultra mikro (UUM). Terhadap pelaku usaha ini, BUMDes berperan sebagai penyedia produk-produk yang dibutuhkan oleh para pelaku UM/UUM dan barang baku sebagai faktor produksi IRT/kerajinan. Melalui skema ini, para pelaku UM/UUM dan IRT/kerajinan tidak lagi keluar desa untuk memperoleh produk/barang yang mereka butuhkan. Di samping itu, para pelaku usaha ini bisa menekan cost, seperti baiya transportasi, dalam pengadaan produk/barang yang butuhkannya. Menurut Kurniawan dan Firmansyah, skema seperti ini, selain memang dibutuhkan oleh masyarakat, juga sebagai strategi untuk menguatkan peran BUMDes sebagai solusi ekonomi di perdesaan. ${ }^{31}$

Di sisi lain, BUMDes juga berposisi sebagai demander. Pada posisi ini, BUMDes menyerap produk atau komoditi yang dihasilkan masyarakat desa. Produk atau komoditi yang diserap bisa diolah atau menjadi produk/barang jualan BUMDes yang bisa didistribusikan kepada masyarakat atau menjalin kerjasama dengan BUMDes desa lain. Menjalin kerjasama dengan BUMDes lain sangat mungkin dilakukan karena sudah diatur dalam regulasi. ${ }^{32}$ Skema seperti ini sangat dibutuhkan di perdesaan dan dapat menghadirkan kemaslahatan yang maksimal bagi perekonomian masyarakat desa, terutama bagi pemilik industri rumah tangga (IRT, kerajinan). IRT di perdesaan sering kali menghadapi kesulitan dalam hal mendistribusikan produk yang mereka hasilkan. Karena kendala ini, tidak jarang kemudian IRT mengalami stagnan, bahkan tidak sedikit yang gulung tikar. Untuk mengatasi kendala ini, BUMDes bisa berperan sebagai distributor. BUMDes bisa menjalin kerjasama dengan BUMDes lain untuk pendistribusian produk yang diserap dari masyarakat. Dari sisi pendanaan, Unit Pembiayaan Syariah (UPS) menyalurkan pembiayaan bagi pelaku usaha yang membutuhkan tambahan modal usaha. Kemitraan seperti ini, menurut Wiagustini, sangat bagus sebagai strategi untuk menunjang kinerja usaha masing-masing. ${ }^{33}$

Melalui skema seperti ini, perputaran uang akan lebih maksimal dan berpusat di seputaran desa itu sendiri. Perputaran uang secara masif yang terjadi akan berdampak pada pergerakan ekonomi. Pergerakan ekonomi, pada akhirnya akan berdampak pada pertumbuhan ekonomi masyarakat desa. Dari skema ini pula terlihat bahwa bisnis yang terjalin antara BUMDes dengan masyarakat membentuk siklus yang saling memberi kemaslahatan tanpa merugikan usaha satu sama lain.

\section{Implementasi Akad Pembiayaan Berbasis Kemitraan}

BUMDes dalam menjalankan usahanya di sektor pembiayaan dapat menggunakan beberapa akad yang selama ini dikenal dalam dunia perbankan. Akan tetapi, harus dicatat bahwa dalam mengimplementasikan akad-akad tersebut harus berbasis pada kemitraan yang berorientasi pada pemberdayaan usaha agar bertumbuh. Pembiayaan harus mampu

${ }^{31}$ Kurniawan and Irman Firmansyah, 'Development of Village Owned Enterprises (Bumdes) As a Solution To Achieve Mandiri Village', International Journal of Business and Economic Affairs, 3.5 (2018), 185-94 <https://doi.org/10.24088/ijbea-2018-35001>.

${ }^{32}$ Sitta Saraya, 'The Civil Law Review of the Role of Joint Village Owned Business Entities (BUMDesa Bersama) as the Subject of Civil Law', Journal of Private and Commercial Law, 2.2 (2018), 101-12.

${ }_{33} \mathrm{Ni}$ Luh Putu Wiagustini, 'Partnership Strategy of Village Owned Enterprises ( Village Credit Institutions and Village Markets ) in Denpasar City, Indonesia', International Journal of Economics, Commerce and Management, III.4 (2015), 1-20. 
memberi kontribusi terhadap perkembangan usaha yang dijalankan masyarakat yang menjadi mitra. Oleh karena itu, untuk merealisasikan tujuan seperti itu, BUMDes harus melakukan trobosan dalam mengiplementasikan akad-akad yang digunakan dan harus komitmen dalam mengaplikasikannya.

Pembiayaan yang berorientasi pada pemberdayaan usaha mitra dapat dilakukan dengan cara BUMDes sebagai pemilik modal (shahib al-mal) menjalin kemitraan dengan pelaku usaha yang bergerak pada produk atau komoditi yang menjadi kebutuhan calon nasabah. Selain menjalin kemitraan dengan usaha masyarakat, Unit Pembiayaan Syariah (UPS) BUMDes juga dapat menjalin kerjasama dengan Unit Perdagangan Umum (UPU) yang dimiliki BUMDes itu sendiri. BUMDes rata-rata memiliki beberapa unit usaha berbeda, sehingga antar unit usaha ini bisa menjalin kemitraan dalam hal memenuhi kebutuhan nasabah. Misalnya, UPS menjalin kerjasama dengan UPU untuk memenuhi kebutuhan seorang nasabah. UPS memberikan pembiyaan (modal) berupa barang yang dibutuhkan nasabah. Barang yang dibutuhkan nasabah tersebut, pengadaannya dapat dilakukan oleh UPU. Sehingga pola ini terjalin kemitraan internal antar unit usaha BUMDes itu sendiri. Melalui pola ini, ketika menggunakan akad murabahah, maka yang diterima nasabah bukan berupa uang melainkan barang yang mereka butuhkan.

Pola pembiayaan berbasis kemitraan ini dapat digambarkan melalui skema berikut:

Gambar 2

Skema Pembiayaan Berbasis Kemitraan

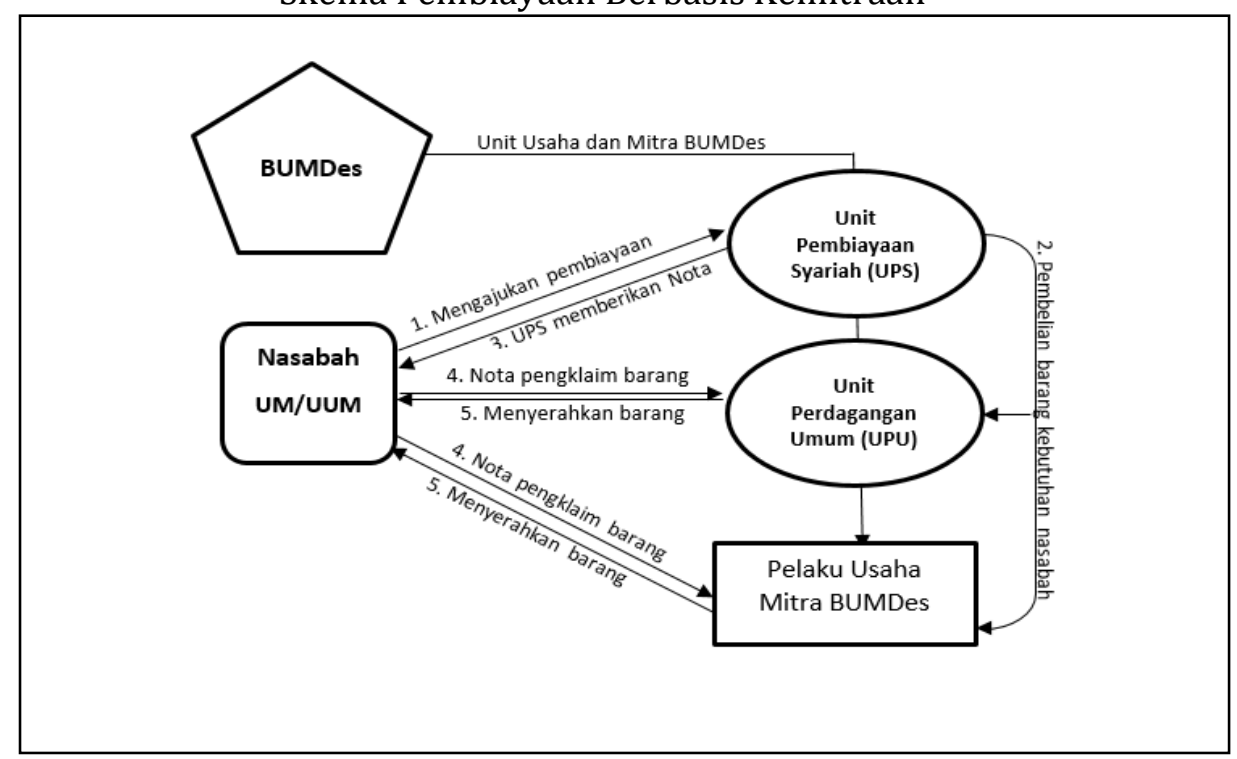

Skema di atas mengilustrasikan bahwa, setelah pengajuan pembiayaan nasabah disetujui, selanjutnya UPS memberi nota kepada nasabah senilai harga barang pembiayaan yang disetujuinya. Nasabah menggunakan nota tersebut untuk mengklaim barang yang dibutuhkannya kepada penyedia barang yang telah menjalin kemitraan dengan UPS, yaitu bisa dari pelaku usaha dari kalangan masyarakat atau dari UPU BUMDes itu sendiri. Mitra usaha, baik dari masyarakat atau UPU, akan menggunakan nota yang diberikan nasabah untuk mengklaim sejumlah uang (sesuai nilai nota) sebagai pembayaran atas barang yang diberikannya kepada nasabah. Melalui skema seperti ini, terlihat jelas bahwa pola ini benarbenar mencerminkan murabahah sebagai akad riil jual-beli, karena yang diterima nasabah 
adalah barang, bukan uang. Di sisi lain, skema ini menggambarkan akad pembiayaan syariah adalah mudah, dapat dipahami oleh masyarakat awam.

Skema seperti ini bisa diimplementasikan dalam berbagai akad yang tersedia dan dalam berbagai sektor, baik sektor riil produktif atau konsumtif. Dalam sektor pertanian misalnya, calon nasabah bisa mengajukan pembiayaan untuk biaya tani. Semua kebutuhan pertanian, mulai dari kebutuhan berupa benih sampai tenaga penggarap bisa dibiyai oleh UPS. Polanya sama, UPS akan memberikan nota sejumlah kebutuhan yang diajukan nasabah. Untuk upah penggarap dan tanam misalnya, nasabah cukup memberikan nota yang diterimanya dari UPS kepada koordinator penggarap, kemudian koordinator atau penerima nota akan melakukan penukaran nota dengan uang kepada UPS. Demikian pula pembiayaan pada sektor konsumtif pembangunan atau renovasi rumah, bisa berlaku pola yang sama. Nasabah mengajukan nota kepada toko bangunan atau material, kemudian UPS akan melakukan pembayaran kepada pemilik toko yang mengajukan nota sesuai harga barang atau material yang sudah diterima nasabah. Melalui pola ini, uang akan lebih banyak berputar di desa sehingga akan berdampak pada pergerakan ekonomi yang positif.

Skema pembiayaan dengan pola seperti ini sangat rasional dilakukan di perdesaan melalui BUMDes. Karakteristik masyarakat perdesaan yang bersifat guyub menjadi pendukung. Harmoni sosial masih dapat dijumpai di tengah-tengah kehidupan masyarakat perdesaan. Modal sosial yang masih kental sperti ini akan memudahkan untuk melakukan sosialisasi dan pemahaman kepada masyarakat. Mobilitas masyarakat pengguna jasa BUMDes lebih bisa dikondisikan karena secara wilayah-geografis sangat memungkinkan dan lebih mudah dijangkau. Sehingga kesepakatan-kesepakatan bersama lebih mudah untuk dibentuk menjadi satu komitmen bersama.

Berbeda halnya dengan bank umum atau BPR yang secara kelembagaan dan cakupan wilayahnya lebih luas dan beragam, sulit untuk mengimplementasikan akad murabahah atau lainnya seperti itu, seringkali yang dilakukan adalah penyandingan akad. Misalnya, murabahah disandingkan dengan wakalah sehingga dalam implementasinya, yang diterima nasabah adalah uang, bukan barang. Penyandingan akad seperti ini, walaupun sah secara syariah, akan tetapi kerap membingungkan masyarakat. Mayoritas masyarakat memahami murabahah adalah akad jual-beli, lazimnya jual-beli adalah barang dibeli dengan uang. Sementara dalam praktiknya di perbankan, yang diterima nasabah adalah uang sehingga hal ini seringkali memicu stigma negatif dari masyarakat, bank syariah dianggap tidak berbeda dengan bank konvensional yang menggunakan sistem kredit.

\section{Mitigasi Risiko Pendekatan Kontekstual: Sekenario Menghindari Non Performing Loan}

Risiko dalam suatu pembiayaan merupakan suatu keniscayaan yang sulit dihindari. Keniscayaan risiko mengharuskan adanya manajemen risiko yang tepat untuk menghindarinya. Risiko dalam pembiayaan syariah memiliki keunikan tersendiri dibanding sistem kredit. Risiko unik yang dimaksud diantaranya risiko kepatuhan syariah, risiko pembiayaan, risiko bagi hasil, risiko investasi, dan sebagainya. Mengenal risiko secara baik dan benar adalah salah satu instrumen untuk merumuskan manajemen risiko dengan tepat. Menurut Wahyudi dkk, Risiko dilihat dari penyebab dan dampak yang ditimbulkannya ada dua macam, risiko nonbisnis dan risiko bisnis. Risiko nonbisnis timbul akibat dari kejadiankejadian yang tidak terkait dengan bisnis tapi memberi dampak secara langsung terhadap bisnis sehingga risiko ini dinamakan risiko murni. Sedangkan risiko bisnis merupakan risiko 
yang muncul dari kegiatan bisnis karena kesalahan atau ketidakakuratan analisis yang dilakukan oleh pihak terkait. ${ }^{34}$

Dua bentuk risiko tersebut membutuhkan mitigasi yang tepat agar tidak menimbulkan efek yang mengancam kesehatan suatu lembaga keuangan yang bergerak dalam sektor pembiayaan. Risiko nonbisnis, umumnya lembaga keuanga seperti bank, memitigasi dampak risiko dengan berbagi risiko dengan perusahaan asuransi. Sedangkan untuk risiko bisnis tidak bisa dilakukan transfer risiko kepada pihak lain. ${ }^{35}$ Oleh karena itu, lembaga bisnis yang bersangkutan harus memiliki metode tersendiri yang disesuaikan dengan karakteristik risiko dari bisnis yang dijalankan.

Keunikan dalam konteks pembiayaan syariah juga terjadi akibat dari multi akad yang bisa digunakan. Di antara macam-macam akad tersebut, bentuk akad mudharabah merupakan akad yang sarat dengan risiko. Menurut Muhammad, risiko akad mudharabah yang paling menonjol adalah masalah agency. ${ }^{36}$ Masalah agency adalah masalah kualifikasi dan kualitas kejujuran dan keamanahan dari pengelola bisnis (mudharib). Oleh karena itu, masalah ini adalah masalah eksternal lembaga pemberi pembiayaan (shahib al-mal) yang harus disikapi dengan prinsip kehati-hatian. Prinsip kehati-hatian ini dapat disikapi dengan membuat suatu pola manajemen risiko yang, selain dari teori-teori yang ada, sesuai dengan karakteristik dan struktur kultural masyarakat lokal. ${ }^{37}$ Mengaitkelindankan kultur kearifan lokal (local wisdom) dengan aktivitas bisnis akan membentuk suatu integrasi yang solid untuk mengkonstruksi solusi bisnis yang fundamental. ${ }^{38}$ Konstruksi fundamental ini bisa disebut sebagai manajemen risiko kontekstual, yaitu mitigasi risiko dengan pendekatan struktur kultural masyarakat lokal.

Manajemen risiko kontekstual dalam konteks pengelolaan BUMDes berbasis syariah ini dapat digambarkan melalui skema berikut:

Gambar 3

Skema Mitigasi Risiko

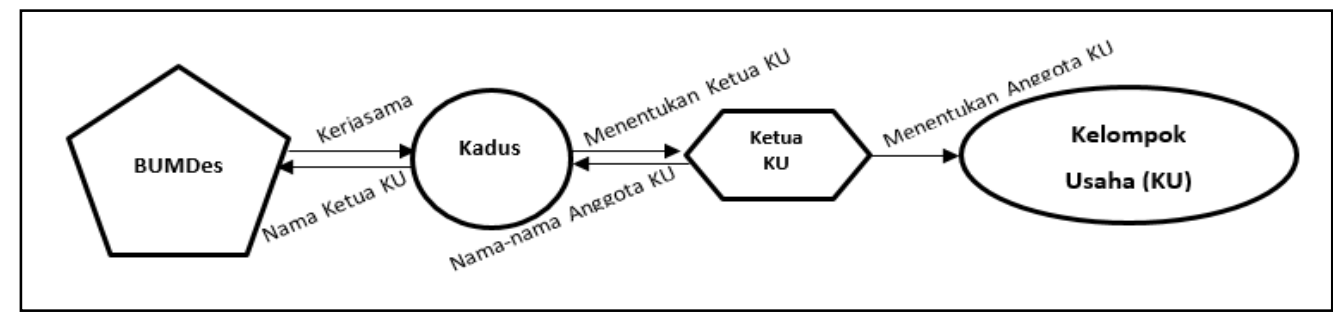

Skema ini menggambarkan bahwa BUMDes menerapkan dua metode sebagai instrumen dalam memitigasi risiko pembiayaan, yaitu kooptasi aparatur desa dan mengadopsi pola grameen bank. Kooptasi aparatur desa yang dimaksud dalam hal ini adalah menjalin kerjasama dengan aparatur desa, yaitu kepala dusun (Kadus) di masing-masing

\footnotetext{
34 Imam Wahyudi and others, Manajemen Risiko Bank Islam (Jakarta: Salemba Empat, 2013).

35 Wahyudi and others.

${ }^{36}$ Muhammad, Manajemen Pembiayaan Mudharabah Di Bank Syariah (Jakarta: Raja Grafindo Persada, 2008).

37 Agus Surono, 'The Role of the Village Community As a Form of Local Wisdom in Realizing AntiCorruption Culture':, Asia Pasific Fraud Journal, $3.1 \quad$ (2018), 133-43 <https://doi.org/10.21532/apfj.001.18.03.01.16>.

38 Pradja.
} 
dusun. Kooptasi kadus dilakukan dengan skema kerjasama bukan sebagai pengelola harian. ${ }^{39}$ Sehingga status para kadus di sini adalah mitra yang dimohonkan kerjasamanya dalam mengembangkan dan membesarkan BUMDes untuk kemaslahatan bersama. Fungsi kadus dalam hal ini adalah sebagai agen untuk menyeleksi dan menentukan ketua dari kelompok usaha yang akan memperoleh pembiyaan. Ketua kelompok usah akan bertanggungjawab menyeleksi dan menentukan anggota kelompoknya. Sehingga pertanggungjawabannya bersifat searah: ketua kelompok bertanggujawab kepada kadus, kadus bertanggujawab kepada BUMDes.

Kenapa harus kadus? karena kadus adalah aparatur yang berada di akar rumput (grass roots) dalam struktur keorganisasian pemerintahan. Penghargaan dan penghormatan warga terhadap kadus relatif masih terjaga, walaupun tidak semuanya, dibandingkan pengharagaan dan penghormatan terhadap aparatur atau pejabat di atasnya. Hal ini desebabkan, kadus dipilih langsung oleh warga dusun sehingga kadus adalah termasuk jabatan politis. Karena ini adalah jabatan politis maka kadus akan tertuntut untuk memberi pelayanan yang terbaik bagi warganya dalam rangka mempertahankan elektabilitasnya. ${ }^{40} \mathrm{Di}$ samping itu, apabila ia berbuat yang menyalahi janjinya maka warga dengan sangat mudah untuk melakukan protes terhadapnya karena relasi antara keduanya yang sangat intens. ${ }^{41}$ Mereka menjalani kehidupan sehari-hari bersama dalam lingkungan dusun yang secara geografis tidak begitu luas.

Interaksi sosial secara intens yang terjadi antara kadus dengan warganya menyebabkan seorang kadus sangat paham terhadap karakter setiap warganya. Interaksi sosial yang terjalin dapat dikategorikan sebagai proses verifikasi panjang yang dilakukan oleh seorang kadus sehingga kadus dapat menyelami karakter warganya dengan sangat baik. Dengan demikian, kadus paham betul bahwa yang direkomendasikannya adalah warga yang dapat dipertanggungjawabkan komitmennya. Atas dasar ini maka kadus sebagai agen yang bertanggungjawab atas pembiayaan menjadi sangat kuat posisinya sebagai instrumen meminimalisir risiko berupa Non Performing Loan (NPL). ${ }^{42}$

Pendekatan kedua adalah mengadopsi pola grameen bank. Pola grameen bank memiliki lima indikator program.43 Pertama, metodologi pinjaman sederhana dan tanpa agunan fisik. Proses pembiayaan yang sederhana, tidak berbelit dan tanpa agunan merupakan pola yang sangat dibutuhkan oleh masyarakat pengusaha, terutama pelaku usaha ultra mikro dan mikro (UUM). Pelaku UUM tidak terjangkau oleh pembiayaan sering kali terkendali oleh syarat administrasi yang diwajibkan pihak bank. Mereka tidak memiliki

\footnotetext{
${ }^{39}$ Larangan perangkat desa menjadi pengelola BUMDes tertuang dalam Permendesa No. 4 Tahun 2015. Permendesa ini menyatakan bahwa organisasi pengelola BUMDes terpisah dari organisasi pemerintah desa.

${ }^{40}$ Strategi semacam ini dalam ekonomi politik disebut sebagai teori public choice. Lihat Ahmad Erani Yustika, Ekonomi Politik: Kajian Teoritis Dan Analisis Empiris (Yogyakarta: Pustaka Pelajar, 2014).

${ }^{41}$ Oleh karena itu, dalam konteks seperti ini, Downs mengistilahkan politisi sebagai pedagang yang menyediakan barang dan jasa berupa barang publik yang bisa ditukar dengan hak pilih yang dimiliki warga dan warga berposisi sebagai konsumen. Lihat Anthony Downs, An Economic Thery of Democracy (New York: Harper \& Row, 1957).

${ }^{42}$ Pola ini adalah salah satu inovasi dalam mitigasi risiko yang secara kontinyu harus dilakukan dalam sistem finansial. Inovasi dalam sistem finansial, menurut Schumpeter, mutlak dilakukan untuk mempertahankan stabilitas dalam siklus bisnis. Lihat A. Prasetyantoko, Bencana Finansial: Stabilitas Sebagai Barang Publik (Jakarta: Penerbit Buku Kompas, 2008).

${ }^{43}$ Safaah Restuning Hayati, Pemberdayaan Ekonomi Perempuan Miskin Dengan Pola Grameen Bank (Jakarta: Intjati, 2014). 
kemampuan dan keterampilan dalam menyusun manajemen usahanya dengan baik sesuai standar perbankan. Kendala inilah yang kemudian menjadi sebab pelaku UUM tidak bisa menjangkau beberapa program pembiayaan atau kridit, termasuk kredit murah yang telah diprogramkan oleh pemerintah, seperti KUR.

Kedua, menggunakan sistem tanggung renteng. Sistem tanggung renteng dalam konteks pembiayaan oleh BUMDes akan sangat efektif sebagai cara mengelola risiko. Hal ini dikarenakan mindset masyarakat perdesaan masih memandang bahwa dana yang bersumber dari dana desa adalah uang pemerintah yang tidak harus dikembalikan. Mindset ini masih terpatri dalam benak kebanyakan masyarakat perdesaan hingga saat ini. Melalui pola tanggung renteng maka mindset ini dapat dirubah karena polanya dalam satu kelompok ada satu anggota yang akan menjadi penanggungjawab atas kewajiban anggota kelompoknya. Penanggungjawab atau ketua kelompok akan dipilih dari orang yang dipandang cakap dan memiliki integritas tinggi yang ditentukan oleh kadus yang sangat paham atas karakter warganya. Dengan demikian, setiap anggota kelompok, pertama kali akan berhadapan dengan ketua kelompok dan kemudian kadus.

Ketiga, kewajiban menabung setiap minggu. Kewajiban menabung setiap minggu tidak ditentukan nominalnya. Titik tekan dari pola ini adalah membiasakan masyarakat untuk memiliki tabungan sebagai sikap antisipasi atas kebutuhan yang tidak terduga di masa mendatang. Dari penghasilan yang diperoleh agar tidak dihabiskan semuanya. Setidaknya ada yang disisakan untuk tabungan walaupun nominalnya kecil. Dengan pola ini maka masyarakat sesungguhnya sedang dididik untuk tidak hidup boros walaupun seberapa kecil penghasilan yang diperolehnya. Menabung harus menjadi budaya yang bisa mengubah pola konsumsi masyarakat agar tatanan ekonominya menjadi lebih terpola dan terarah.

Keempat, ada produk non-keuangan. Produk non-keuangan BUMDes dalam konteks ini adalah memberi pemberdayaan kepada mitra atau pelaku usaha yang menggunakan jasa BUMDes. Mayoritas usaha di perdesaan adalah usaha ultra mikro dan mikro serta beberpa kerajinan lokal. Kendala terbesar yang dihadapi pelaku usaha tipe ini adalah manajemen dan jaringan untuk mendistribusikan produknya. ${ }^{44}$ BUMDes dapat menjadi solusi bagi mereka dengan memberikan pembinaan-pembinaan teknis dan membangun jaringan pasar bagi mereka. Sesuai dengan pola BUMDes business networkbusiness network yang telah dikemukakan di atas, BUMDes bisa menjalin kerja sama dengan BUMDes-BUMDes antar kabupaten atau bahkan lintas provinsi. BUMDes sangat memiliki potensi ini karena saat ini BUMDes telah memiliki forum tersendiri, dari tingkat kabupaten hingga nasional.

Kelima, peminjam harus memiliki usaha mikro. Nasabah yang menjadai ceruk pasar BUMDes yang paling utama adalah masyarakat yang memiliki usaha, diutamakan usaha ultra mikro dan mikro. BUMDes sebagai lembaga ekonomi desa harus berperan maksimal dalam mengakomodasi kebutuhan sektor ini. Sektor usaha ini sering kali luput dari pembiayaan atau kredit yang disalurkan oleh bank-bank besar karena tidak memenuhi kriteria (unbankable). BUMDes harus ketat dalam menentukan nasabahnya yaitu masyarakat yang benar-benar memiliki usaha. Hal ini penting karena tujuan utama BUMDes adalah menghidupkan perekonomian masyarakat desa. ${ }^{45}$ Menggerakkan ekonomi dari bawah; dari pinggiran perdesaan yang ada hingga keplosok negeri. Selain itu, komitmen ini harus berjalan dalam BUMDes berbasis syariah karena akad-akad yang digunakan dalam sistem syariah

44 Tulus Tambunan, Usaha Mikro Kecil Dan Menengah Di Indonesia (Jakarta: LP3ES, 2012).

45 Agus Suriadi and others, 'The Applicative Model of the Village_Owned Enterprises (Bumdes) Development in North Sumatera', Global Journal of Arts, Humanities and Social Sciences, 3.12 (2015), 48-62<www.eajournals.org>.

Iqtishadia: Jurnal Ekonomi dan Perbankan Syariah 
harus berbasis pada transaksi riil, seperti murabahah dalam skema jual beli. Melalui pola ini maka praktik akad-akad transaksi syariah bisa diimplementasikan sesuai dengan teori dasarnya, sebgaimana yang telah dijelaskan di atas, yang mudah dimengerti dan dipahami oleh masyarakat awam.

Melalui dua skema mitigasi risiko ini, akan sangat efektif di tingakt perdesaan karena karakter masyarakat desa yang relatif masih bisa dikontrol langsung oleh kadus. Demikian pula dengan mengadopsi pola grameen bank dengan indikator sebagaimana dijelaskan di atas, akan sangat memungkinkan menjadi solusi yang efektif dalam memitigasi risiko. Risiko yang dikelola secara baik akan menjadikan BUMDes menjadi inklusi keuangan non bank syariah yang tangguh sehingga BUMDes bisa menjadi motor penggerak pertumbuhan ekonomi di perdesaan.

Inklusi keuangan non bank seperti BUMDes di perdesaan akan menjadi semacam oase di tengah gurun sahara. BUMDes akan menjadi harapan baru bagi keum miskin di perdesaan. Karena inklusi keuangan sejatinya ada memang berperan untuk memberi pemberdayaan terhadap masyarakat miskin dan untuk memberi kesejahteraan yang lebih baik. ${ }^{46}$ Apabila fungsi ini bisa dilakukan dengan baik oleh BUMDes maka BUMDes bisa menjadi kompetitor bagi iknklusi keuangan lainnya seperti Koperasi Mitra Dhuafa. Koperasi Mitra Dhuafa, di beberapa wilayah telah menunjukkan hasil yang mampu merubah kehidupan perempuan miskin yang tidak berdaya menjadi terberdayakan. ${ }^{47}$

\section{Implikasi BUMDes Berbasis Syariah terhadap Pemberdayaan Sosial Ekonomi Masyarakat Perdesaan}

Diskursus kemiskinan dan ketimpangan bukan hanya menjadi masalah sosial di Indonesia, seluruh negara mengalaminya, tidak terkecuali negara maju. Indonesia memiliki penduduk sebanyak 238,5 juta jiwa, 26,42 juta diantaranya adalah masyarakat miskin. 6,56 $\%$ masyarakat miskin ada di perkotaan dan $12,60 \%$ ada di daerah perdesaan ${ }^{48}$ yang tersebar dari Sabang sampai Merauke dan dari Pulau Miangas sampai Rote. Pemerintah telah melakukan berbagai macam program pembangunan sosial untuk mengatasinya. Dibanyak kasus, pembangunan sosial yang dilakukan belum menyentuh persoalan-persoalan ekonomi yang dihadapi masyarakat sehingga kemiskinan masih menjadi isu penting setiap daerah di Indonesia.

Beberapa data yang dipublikasikan menunjukkan adanya penekanan angka kemiskinan yang terjadi. Basis data yang digunakan adalah tingkat pendapatan per kapita (income per kapita). Pendapatan per kapita hingga saat ini masih menjadi perdebatan tingkat akurasinya sebagai tolak ukur keberhasilan pembangunan. Menurut Hikmat, metode ini tidak mampu memberi gambaran utuh tentang fakta, hanya menyajikan data berupa angka-angka. Oleh karena itu, para hali ekonomi memandang bahwa pendapatan per kapita bukan satusatunya yang bisa menjadi tolak ukur. Bagaimana pendapatan tersebut didistribusikan secara seimbang kepada masyarakat tidak mampu disajikan melalui income per kapita. Demikian juga tentang siapa sesungguhnya yang merasakan hasil pembangunan yang dilakukan juga

${ }^{46}$ Zelin Nurfadia Sidik, Noer Azam Achsani, and Syamsul Hidayat Pasaribu, 'Financial Inclusion and Demand for Money: A Dynamic Panel Data Approach', Signifikan: Jurnal Ilmu Ekonomi, 7.2 (2018), 137$48<$ https://doi.org/10.15408/sjie.v7i2.6838>.

${ }^{47}$ Hayati.

48 https://www.bps.go.id/website/images/Kemiskinan-Rilis-Juli-2020-ind.jpg, diakses, 19 Agustus 2020. 
tidak bisa diketahu melalui income per kapita. ${ }^{49}$ Untuk mengetahuinya adalah dengan melihat fakta kehidupan masyarakat yang ada di desa-desa. Cara ini adalah kunci utama yang bisa dilakukan untuk memotret dampak sosial ekonomi masyarakat dari sebuah pembangunan.

Selama ini yang digunakan untuk memotret hasil pembangunan adalah melihat pertumbuhan GNP (gross nasional product). Pertumbuhan GNP yang tinggi diasumsikan berpengaruh signifikan terhadap penyerapan kerja dan kesempatan-kesempatan ekonomi serta kesejahteraan masyarakat. Oleh karenanya, paradigma pembangunan yang digunakan adalah top up sehingga harapannya akan "menetes ke bawah" (trickle down effect). Konsep pembangunan seperti ini cenderung menyampingkan pemberdayaan komunitas (community development) yang berorientasi pada pembangunan masyaarakat desa. ${ }^{50}$ Metode inilah yang digunakan pada periode pemerintahan-pemerintahan yang lalu. Saat ini, mulai Tahun 2014 bersamaan dengan adanya dana desa, selain top up, konsep yang digunakan adalah bottom up (membangun dari bawah), yaitu dari desa, sehingga muncul jargon "desa membangun."

Konsep desa membangun ini salah satu komponennya adalah masing-masing desa diarahkan memiliki BUMDes. Sebagaimana data yang dipaparkan pada bagian latar belakang bahwa saat ini jumlah BUMDes tidak kurang dari 50.199 unit yang tersebar di seluruh Indonesia. BUMDes sebagai penggerak perekonomian dari tingkat desa mengalami kondisi dan peran yang berbeda-beda. Ada yang berperan aktif sebagai solusi perekonomian masyarakat desa ${ }^{51}$ dan ada yang belum berjalan secara maksimal karena berbagai kendala. ${ }^{52}$ Untuk memaksimalkan fungsi dan peran BUMDes sebagai lokomotif ekonomi masyarakat memerlukan trobosan-torbosan baru dalam pengelolaannya. ${ }^{53}$ Alternatif yang ditawarkan dalam tulisan ini adalah pengelolaan BUMDes berbasis syariah dengan skema sebagaimana yang telah dipaparkan di atas. Skema ini bisa menjadi alternatif dengan fokus akhirnya menjadi solusi pemberdayaan sosial ekonomi masyarakat.

Fokus utama meningkatkan pemberdayaan sosial ekonomi dapat dilihat dari model jaringan bisnis yang mengutamakan kemaslahatan. Mengutamakan kemaslahatan akan berdampak pada penguatan usaha bersama. Usaha-usaha masyarakat sekitar yang sudah ada akan diperkuat, bukan disaingi sehingga menjadi lemah. BUMDes hanya akan membuka unit usaha yang belum ada. Melalui skema seperti ini akan terjalin kersama yang saling mengisi dan saling mengutkan untuk maju bersama. Dari sisi implementasi akad juga mencerminkan pemberdaayaan untuk maju dan saling menguatkan. Implementasi akad berbasis pada kerjasama yang saling memanfaatkan masing-masing potensi yang dimiliki. BUMDes memanfaatkan potensi yang dimiliki masyarakat berupa produk atau komoditi yang dibutuhkan nasabah BUMDes, dan masyarakat memanfaatkan BUMDes dari sisi permodalan dan jaringan distribusi produk barang atau jasa. Dari skema ini kemudian muncul siklus ekonomi di mana uang lebih banyak berputar di perdesaan sehingga sosial ekonomi masyarakat akan lebih terbedayakan.

\footnotetext{
${ }^{49}$ Harry Hikmat, Strategi Pemberdayaan Masyarakat (Bandung: Humaniora Utama Press, 2010).

${ }^{50}$ Hikmat.

51 I Nyoman Sumaryadi and Romi Saputra, "The Role of The Village Business Agency As Creative Economic Implementation in Order of Community Empowerment of Villages of Cagak Road Subang District West Java Province', International Journal of Information Technology and Business Management, 58.1 (2017), 8-21 <https://www.tijoss.com/58th volume/I Nyoman TIJOSS Journal.pdf>.

52 Kiky Srirejeki, 'Empowering the Role of Village Owned Enterprises (BUMDes) for Rural Development: Case of Indonesia', Journal of Accounting, Management, and Economics, 20.1 (2018), 5$10<$ http://jos.unsoed.ac.id/index.php/jame/article/view/1018/727>.

53 Yusuf and others.
} 
Pola mitigasi risiko yang digunakan juga mengarah pada sebesar-besar kepentingan bersama. Melibatkan para kepala dusun untuk menanamkan rasa kepemilikin dan tanggungjawab bersama terhadap BUMDes dan kemaslahatan sosial ekonomi masyarakat. Begitu juga dengan pola grameen bank. Pola grameen bank disesuaikan dengan kondisi di masing-masing desa yaitu dengan metode kelompok. Metode ini dipilih karena semua warga, terutama warga disatu dusun, saling mengenal dan dapat menentukan dengan siapa mereka akan berkelompok untuk mendapat pembiayaan. Pola grameen memberi pembiayaan hanya kepada mereka yang memiliki usaha mikro bukan untuk konsumtif. Tujuannya untuk mengubah status sosial kaum miskin. ${ }^{54}$ Dengan demikian, pola kerja bisnis BUMDes berbasisi syariah ini akan menjadi lokomotif penggerak ekonomi sehingga sosial ekonomi masyarakat lebih terberdayakan dan bisa melepaskan diri dari perangkap kemiskinan (poverty trap).

Selama ini, masayarakat desa identik dengan kemiskinan. Masyarakat desa sangat sulit melepaskan diri dari perangkap kemiskinan. Fenomena kemiskinan di perdesaan seolah-olah saling mengunci. Perangkap kemiskinan telah membuat masyarakat desa semakin lemah, baik secara finansial maupun non finansial. Salah satu penyebab dari fenomena ini adalah masyarakat perdesaan tidak cukup memiliki kapabilitas. Oleh karena itu, peningkatan kapabilitas adalah keniscayaan yang harus dilakukan. Peningkatan kapabilitas bagi masyarakat perdesaan akan menjadi modal utama bagi mereka untuk berkompetisi memperoleh peluang ekonomi yang lebih baik. Meningkatkan kapabilitas masyarakat sama artinya dengan berupaya meningkatkan kesejahteraan masyarakat itu sendiri. ${ }^{55}$ Hal ini selaras dengan apa yang dikemukakan Amartya Sen, bahwa konsep kapabilitas merupakan cara berpikir tentang kesejahteraan manusia. Karena pada dasarnya pendekatan kapabilitas adalah suatu kerangka yang mengakomodasi analisis sosial, ekonomi, dan politik. 56 Peningkatan kapabilitas ini bisa dilakukan melalui alternatif BUMDes berbasisi syariah dengan skema pengelolaan sebagaimana yang dikemakan di atas. Apabila hal ini dapat dimaksimalkan, permasalahan-permasalahan sosial ekonomi yang dihadapi masyarakat perdesaan bisa segera menemukan solusinya secara adil dan sustainable.

\section{PENUTUP}

BUMDes memilik peran strategis sebagai penggerak ekonomi dari akar rumput (perdesaan). Peran sebagai penggerak ekonomi ini bisa dimaksimalkan dengan pola pengelolaan berbasis syariah. Pengelolaan berbasis syariah yang mengutamkan kemaslahatan bersama melalui kemitraan dengan pelaku usaha yang terdiri dari masyarakat sekitar desa. Menjalin kemitraan dengan para pelaku usaha, baik dalam hal pembiayaan atau jasa lainnya, BUMDes mengimplementasikan akad berbasis pada kerjasama. Akad yang dibasiskan pada kerjasama dapat mendorong terciptanya jaringan usaha antar BUMDes dan pelaku usaha yang sama-sama memberi manfaat secara proporsional bagi keduanya.

Pengelolaan BUMDes berbasis syariah dari sisi resistensi terhadap NPL memiliki daya tahan yang bisa diuji. Melalui sistem screening nasabah atau mitra dengan melibatkan para kadus akan berdampak pada terjaringnya nasabah yang kredibilitasnya dapat dipertanggungjawabkan. Pola grameen bank yang mensyaratkan nasabah pembiayaan secara

\footnotetext{
54 Hayati.

55 Suhirman, Perbankan Syariah Dan Pemberdayaan Sosial Ekonomi: Peran Pembiayaan Syariah Pada Usaha Mikro (Jakarta: Impressa Publishing, 2015).

56 Bagus Dharmawan, Esai-Esai Nobel Ekonomi, ed. by Bagus Dharmawan (Jakarta: Kompas Media Nusantara, 2008). 
berkelompok juga dapat menjadi pola mitigasi risiko yang efektif karena kewajiban dipikul secara bersama antar anggota atas koordinasi ketua kelompok. Di samping itu, pola grameen bank mensyaratkan pembiayaan hanya diberikan kepada yang memiliki usaha ultra mikro atau usaha mikro. Skema ini akan memberi keuntungan-keuntungan bagi BUMDes dan masyarakat perdesaan secara umum, baik keuntungan finansial maupun dari sisi syariah compliance.

Keuntungan finansial, BUMDes terhindar dari NPL karena pembiayaan disalurkan pada sektor riil produktif dengan kualitas personal nasabah yang sudah discreening dari awal. Bagi masyarakat, pola ini memberi stimulus bagi usaha yang dijalankan karena tambahan modal yang diberikan adalah berupa barang atau komoditi yang merupakan produk utama yang mereka butuhkan untuk diperdagangkan. Sisi syariah compliancenya, BUMDes mengimplementasikan akad-akad syariah sesuai teori dasar yaitu memberikan pembiyaan berupa barang. BUMDes membelikan barang atau produk jadi yang dibutuhkan nasabah bukan memberi pembiayaan dalam bentuk uang tunai. Demikian pula bagi nasabah atau masyarakat, syariah compliance bagi mereka adalah mereka menerima pembiayaan berupa barang sehingga mereka terhindar dari menggunakan uang pembiayaan diluar perjanjian yang disepakati di dalam akad. Melalui pola seperti ini maka perekonomian masyarakat akan tumbuh karena aktifitas ekonomi bergerak di sektor riil produktif sehingga hal ini akan mempercepat pemberdayaan sosial ekonomi masyarakat perdesaan.

\section{DAFTAR PUSTAKA}

Afwa, Ulil, 'Local Economic Development Manifesto: Policy Analysis on the Implementation of Village-Owned State Enterprises', SHS Web of Conferences, 54 (2018), 04002 <https://doi.org/10.1051/shsconf/20185404002>

Al-Ghazali, Saikh Muhammad, Al-Mustashfa (Beirut: Dar al-Fikr)

Al-Syathibi, Al-Muafaqat Fi Ushul Al-Syari'ah (Beirut: Dar al-Ma'arif)

Bachtiar, Palmira, Asep Kurniawan, Gema Satria Mayang Sedyadi, Rendy Diningrat, Ruhmaniyati, and Ulfah Alifia, Laporan Studi Kasus Undang-Undang Desa: Menelusuri Manfaat Belanja Desa (Jakarta: Smeru Research Institite, 2019) < https://smeru.or.id>

Deneulin, Se'verine, and J. Allister McGregor, 'The Capability Approach and The Politics of a Social Conception of Wellbeing', European Journal of Social Theory, 13.4 (2010), 501-19

Dharmawan, Bagus, Esai-Esai Nobel Ekonomi, ed. by Bagus Dharmawan (Jakarta: Kompas Media Nusantara, 2008)

Downs, Anthony, An Economic Thery of Democracy (New York: Harper \& Row, 1957)

Hardijono, Rachmat, Mary unani, A. Erani Yustika, and C. Fajri Ananda, 'Economic Independence Of The Village Through Institutional Village Enterprises (BUMDes)', IOSR Journal of Economics and Finance, 3.2 (2014), 21-30 <https://doi.org/10.9790/593303232130>

Hayati, Safaah Restuning, Pemberdayaan Ekonomi Perempuan Miskin Dengan Pola Grameen Bank (Jakarta: Intjati, 2014)

Hikmat, Harry, Strategi Pemberdayaan Masyarakat (Bandung: Humaniora Utama Press, 2010)

Hosen, Muhammad Nadratuzzaman, Ferry Jie, Syafaat Muhari, and Muhammad Khairman, 'The Effect of Financial Ratios, Maqasid Sharia Index, and Index of Islamic Social 
Suhirman

Reporting to Profitability of Islamic Bank in Indonesia', Al-Iqtishad: Jurnal Ilmu Ekonomi Syariah, 11.2 (2019), 201-22 <https://doi.org/10.15408/aiq.v11i2.11588>

Ibrahim, 'Productivity the Village Owned Enterprises to Improve the Economic Community of Gold Mining Areas in Sumbawa Island, Indonesia', International Journal of Scientific and Technology Research, 9.2 (2020), 235-38

Khallaf, Abdul Wahhab, 'Ilmu Ushul Al-Fiqh (Kairo: Al-Haramain, 2004)

—, Mashadir Al-Tasyri' Al-Islami Fima La Nashsha Fih (Kuwait: Dar al-Qalam, 1972)

Kuncoro, Mudrajad, Mudah Memahami Dan Menganalisis Indikator Ekonomi (Yogyakarta: UPP STIM YKPN, 2013)

Kurniawan, and Irman Firmansyah, 'Development of Village Owned Enterprises (Bumdes) As a Solution To Achieve Mandiri Village', International Journal of Business and Economic Affairs, 3.5 (2018), 185-94 <https://doi.org/10.24088/ijbea-2018-35001>

Mufid, Moh., Ushul Fiqh Ekonomi Dan Kenangan Kontemporer, 2nd edn (Jakarta: Prenanda Media Group, 2018)

Muhammad, Manajemen Pembiayaan Mudharabah Di Bank Syariab (Jakarta: Raja Grafindo Persada, 2008)

Muryanti, Muryanti, 'Towards Social Entrepreneurship in the Village through Village-Owned Enterprises', Society, 8.1 (2020), 163-74 <https://doi.org/10.33019/society.v8i1.161>

Muslim, Moch Bukhori, Saepullah Saepullah, and Any Widayatsari, 'Political Economy From the Perspective of Ibn Khaldun', Al-Iqtishad: Jurnal Ilmu Ekonomi Syariah, 11.1 (2019), 59$74<$ https://doi.org/10.15408/aiq.v11i1.13341>

Muslimin, J M, 'Society, Law and Economy: Contextualizing Ibn Khaldun's Thought', AlIqtishad: Jurnal Ilmu Ekonomi Syariah (Journal of Islamic Economics), 11.July (2019), 167-80

Nahe'i, Imam, and Wawan Juandi, Revitalisasi Ushul Fiqh Dalam Proses Istinbath Hukum Islam (Sirubondo: Ibrahimy Press, 2010)

Nawawi, Ismail, Pembangunan Dan Problema Masyarakat: Kajian Konsep, Model, Teori Dari Aspek Ekonomi Dan Sosiologi (Surabaya: CV. Putra Media Nusantara, 2009)

Nurzaman, Mohamad Soleh, Pengantar Ekonomi Islam: Sebuah Pendekatan Metodologi (Jakarta: Salemba Diniyah, 2019)

Permendesa, 'Peraturan Menteri Desa, Pembangunan Daerah Tertinggal, Dan Transmigrasi No. 5 Tahun 2015 Tentang Penetapan Prioritas Penggunaan Dana Desa', 1-6

Pradja, Juhaya S., Ekonomi Syariah (Bandung: Pustaka Setia, 2015)

Prasetyantoko, A., Bencana Finansial: Stabilitas Sebagai Barang Publik (Jakarta: Penerbit Buku Kompas, 2008)

Razak, Muhammad Rais Rahmat, and B. Sofyan, 'Role of Village-Owned Enterprises in Farming Community Empowerment', International Journal of Advanced Science and Technology, 29.6 Special Issue (2020), 684-91

Saraya, Sitta, 'The Civil Law Review of the Role of Joint Village Owned Business Entities (BUMDesa Bersama) as the Subject of Civil Law', Journal of Private and Commercial Law, 2.2 (2018), 101-12

Sidik, Zelin Nurfadia, Noer Azam Achsani, and Syamsul Hidayat Pasaribu, 'Financial 
Pola Pengelolaan BUMDes Berbasis Syariah Sebagai Alternatif Pemberdayaan Usaha Mikro Masyarakat Perdesaan Inclusion and Demand for Money: A Dynamic Panel Data Approach', Signifikan: Jurnal Ilmu Ekonomi, 7.2 (2018), 137-48 <https://doi.org/10.15408/sjie.v7i2.-6838>

Soto, Hernando de, The Mystery of Capital (t.t.p: Qalam, 2006)

Srirejeki, Kiky, 'Empowering the Role of Village Owned Enterprises (BUMDes) for Rural Development: Case of Indonesia', Journal of Accounting, Management, and Economics, 20.1 (2018), 5-10 <http://jos.unsoed.ac.id/index.php/jame/article/-view/1018/727>

Stamboel, Kemal A., Panggilan Keberpihakan: Stategi Mengakbiri Kemiskinan Di Indonesia (Jakarta: Gramedia Pustaka Utama, 2012)

Sugiyono, Metode Penelitian Kombinasi (Mixed Methods), 8th edn (Bandung: Alfabeta, 2016)

Suhirman, Perbankan Syariah Dan Pemberdayaan Sosial Ekonomi: Peran Pembiayaan Syariah Pada Usaha Mikro (Jakarta: Impressa Publishing, 2015)

Sumaryadi, I Nyoman, and Romi Saputra, 'The Role of The Village Business Agency As Creative Economic Implementation in Order of Community Empowerment of Villages of Cagak Road Subang District West Java Province', International Journal of Information Technology and Business Management, 58.1 (2017), 8-21 <https://-www.tijoss.com/58th volume/I Nyoman TIJOSS Journal.pdf>

Suriadi, Agus, Kasyful Mahalli, Nurman Achmad, and Iskandar Muda, 'The Applicative Model of the Village_Owned Enterprises (Bumdes) Development in North Sumatera', Global Journal of Arts, Humanities and Social Sciences, 3.12 (2015), 48-62 <www.eajournals.org>

Surono, Agus, 'The Role of the Village Community As a Form of Local Wisdom in Realizing Anti-Corruption Culture':, Asia Pasific Frand Journal, 3.1 (2018), 133-43 <https://doi.org/10.21532/apfj.001.18.03.01.16>

Tambunan, Tulus, Usaha Mikro Kecil Dan Menengah Di Indonesia (Jakarta: LP3ES, 2012)

Wahyudi, Imam, Miranti Kartika Dewi, Fenny Rosmanita, M. Budi Prasetyo, Niken Iwani Surya Putri, and Banu Muhammad Haidir, Manajemen Risiko Bank Islam (Jakarta: Salemba Empat, 2013)

Wiagustini, Ni Luh Putu, 'Partnership Strategy of Village Owned Enterprises (Village Credit Institutions and Village Markets ) in Denpasar City , Indonesia', International Journal of Economics, Commerce and Management, III.4 (2015), 1-20

Winarsi, Sri, Agus Widyantoro, Oemar Moechthar, and Universitas Airlangga, 'The Law Principles for Village-Owned Enterprises (BUMDes) Management in Indonesia to Improve the Village's Economy', International Journal of Sociological Jurisprudence, 1.2 (2018), 130-36

Yunus, Muhammad, Bank Kaum Miskin, Terjemah (Tangerang: PT. Cipta Lintas Wacana, 2007)

Yustika, Ahmad Erani, Ekonomi Politik: Kajian Teoritis Dan Analisis Empiris (Yogyakarta: Pustaka Pelajar, 2014)

Yusuf, Edy, Agung Gunanto, Fitrie Arianti, Banatul Hayati, and Development Studies, 'Strategy for the Development of Coastal Village-Owned Enterprises ( Bumdes ) As a Form of Independent', International Journal of Mechanical Engineering and Technology, 10.06 (2019), 160-69 